UNITED STATES DEPARTMENT OF THE INTERIOR

GEOLOGICAL SURVEY

\title{
STRUCTURAL EVOLUTION \\ OF PART OF THE NORTH-TRENDING SEGMENT \\ OF THE SQUAW PEAK FAULT, CAJON PASS, CALIFORNIA
}

\author{
Martin G. Miller ${ }^{\text {I }}$ and Ray J. Weldon ${ }^{2}$
}

Open File Report 89-189

Menlo Park, California

May, 1989

This report is preliminary and has not been reviewed for conformity with USGS editorial standards or with the North American Stratigraphic Code. Any use of trade, product, or firm names is for descriptive purposes only and does not imply endorsement by the U.S. Government.

1. Presently at Dept. of Geological Sciences, University of Washington, Seattle, WA 98195

2. Presently at Dept. of Geological Sciences, University of Oregon, Eugene, OR 97403 


\title{
Structural evolution of part of the north-trending segment of the Squaw Peak fault, Cajon Pass, California
}

\begin{abstract}
The Squaw Peak fault places the Miocene Crowder Formation and pre-Cenozoic basement of the San Bernardino Mountains against the Miocene Cajon (Punchbowl) Formation. The fault consists of two west-northwest-trending low-angle segments which occur at different structural levels separated by a north northeast-trending high-angle segment. Meisling and Weldon (1989) suggested that the low-angle segments are thrust faults and that the high angle segment is a dextral lateral ramp connecting them.

Mapping of the north end of the high-angle segment, at the scale of 1:500, revealed east- and west- directed contractional structures and evidence for later dextral slip on the high-angle segment. Contraction occurred in three stages: 1) east-directed folding and reverse faulting; 2) west-directed backthrusting; 3) northeast-directed thrust faulting and refolding of stage 1 folds. The high-angle fault cuts these structures. The curved surface of the main fault plane and numerous smaller fault-bend axes within the fault zone plunge gently southeast, suggesting predominant lateral slip; "drag" of rocks adjacent to the fault plus an obliquely oriented thrust fault and fold pair suggest the slip was right-lateral.

Three observations suggest that the contraction and strike-slip were part of the same protracted episode: 1) contractional features are spatially related to the Squaw Peak fault; 2) motion on the Squaw Peak fault occurred between 4.2 to $9.5 \mathrm{Ma}$, possibly from 4.2 to $6.2 \mathrm{Ma}$; 3) mobilized gouge fills faults of all stages, suggesting similar conditions during slip. Also, the contractional structures trend obliquely to the Squaw Peak fault and display an apparent clockwise rotation through time, suggestive of Formation over a wrench fault.

The structural evolution of this study area supports the thrust and ramp model for the Squaw Peak fault. Thrust motion on the two gently north-dipping segments of the Squaw Peak fault, before they were connected by the high-angle fault, set up a rightlateral shear couple. The resultant contraction in the stepover region, represented by stages 1 through 3, preceded propagation of the high-angle fault between the two thrust faults. Further slip within the stepover region occurred on the high-angle fault, effectively shutting off the earlier contractional structures.
\end{abstract}


Introduction

The Squaw Peak fault places pre-Cenozoic basement of the San Bernardino Mountains and overlying Miocene Crowder Formation on the east against basement of unknown affinity and overlying Cajon (Punchbowl) Formation on the west. The fault consists of three major segments (Fig. 1). Two of these segments strike west-northwest and dip north, parallel to the average bedding in the Cajon and Crowder Formations. They are separated by a north-northeast striking high-angle segment that cuts bedding in the Crowder and Cajon Formations at high angles.

Near Cajon Pass, $0.5 \mathrm{~km}$ northeast of the DOSECC drill site, the high-angle segment of the Squaw Peak fault and related structures are exposed in railroad cuts into the Cajon and Crowder Formations. These structures involve rocks of both the Cajon and Crowder Formations. Our work along the railroad cuts, reported here, aimed at determining the sense of slip of the high-angle segment and evaluating its possible origin as a lateral ramp in the Squaw Peak fault.

Slip on the Squaw Peak fault occurred between 4.2 and $9.5 \mathrm{Ma}$, possibly between 4.2 and 6.2 Ma (Weldon, 1986; Meisling and Weldon, 1989). It cuts the upper Crowder Formation dated by magnetostratigraphy at $9.5 \mathrm{Ma}$, and is overlain by the Phelan Peak Formation, dated by magnetostratigraphy at 4.2 Ma (Weldon et al., 1984). The Santa Ana thrust, which lies east of the Squaw Peak fault and resembles the Squaw Peak fault in trend, style, probable direction of slip, and stratigraphic associations, slipped after 6.2 Ma (Strathouse, 1982). Weldon (1986) suggested that both faults slipped during the same period of time.

The Pliocene Phelan Peak Formation and overlying early Quaternary formations dip approximately 25 degrees to the north-northwest, reflecting deformation that postdates slip on the Squaw Peak fault. Restoration of the Phelan Peak Formation to horizontal therefore restores the Squaw Peak fault and its associated structures to their 
original orientations. The west-northwest striking segments of the Squaw Peak fault restore to gentle north-dipping surfaces; the north-northeast striking high-angle segment remains at a high angle.

Foster (1980) named the Squaw Peak fault and mapped the high-angle segment in the area around Squaw Peak. Weldon (1986) showed that the fault continues to the west-northwest to where the Phelan Peak Formation and younger alluvium buries its trace. He inferred that the fault continues to the outcrop limit of the Cajon Formation, just southeast of Mountain Top Pass. Weldon (1986) also traced the high-angle segment farther south, across the Cleghorn fault which offsets it left-laterally, and across smaller right-lateral and normal faults of the San Andreas fault system. Farther southeast, a series of west-northwest striking low-angle faults placing San Bernardino basement rocks over probable Cajon Formation (Fig. 1; Meisling and Weldon, 1989) are inferred to be the continuation of the Squaw Peak fault zone. The San Andreas fault cuts the Squaw Peak fault near Cable Canyon.

Because the Squaw Peak fault system juxtaposes two upper Miocene rock units, workers have not been able to use stratigraphic separation as a means to evaluate its principal component of slip. Foster (1980), thinking the Crowder is younger than the Cajon Formation, suggested normal fault motion as a means to juxtapose the two units. Reynolds (1984), however, found Miocene fossils in the Crowder Formation and subsequent work (Weldon, 1984, 1986; Reynolds, 1985; Winston, 1985) showed that the Crowder and Cajon Formations are the same age.

Based on the apparent right-lateral drag of facies boundaries and structures in the Crowder and Cajon Formations, Weldon (1984) suggested the Squaw Peak fault is a strike-slip fault, possibly a pre-existing strand of the near-parallel San Andreas fault zone. Paleomagnetic fold tests on the Crowder Formation, however, failed to show significant rotation about a vertical axis (Weldon, 1986) indicating the fault lacked a large lateral component. Instead, Weldon (1986) and Meisling and Weldon (1989) 
suggested that the Squaw Peak fault was part of the larger Squaw Peak thrust system which carried part of the Crowder basin and underlying basement over the Cajon basin. The thrust system is hypothesized to include the Cedar Springs reverse faults, the Waterman Canyon reverse fault, the Santa Ana thrust, and perhaps late Miocene to Pliocene faults south of the San Andreas fault. In their model, the low-angle, westnorthwest segments of the Squaw Peak fault are thrust faults that occur at significantly different structural levels. The northwestern segment cuts rocks at a relatively shallow level, placing Crowder Formation over uppermost Cajon Formation; the southern segment cuts rocks at a much deeper level, placing San Bernardino Mountains basement over the upper middle Cajon Formation. They suggested that the high-angle segment connects the two thrusts as a dextral lateral ramp. The Cedar Springs, Waterman Canyon, and Santa Ana faults imbricate the upper plate. Meisling and Weldon (1989) noted that 1) the pre-Pliocene geometry of the Squaw Peak fault lends itself easily to such an interpretation, 2) originally south-vergent fold pairs in the Cajon Formation, parallel and adjacent to the west-northwest segments of the fault, indicated shortening perpendicular to the proposed thrust faults, 3) fold pairs and north-dipping reverse faults in the Crowder Formation also indicate shortening perpendicular to the faults, and 4) the Crowder Formation thickens and becomes finer grained towards the west where it is abruptly truncated by the Squaw Peak fault. They suggested that the basin center originally lay west of the fault but was overridden during the south-southwest vergent thrusting.

Ehlig (1988) disputed the importance of the Squaw Peak fault, noting the similarity of the granitic rocks present on both sides of the fault. These rocks form a line from east of the Squaw Peak fault to Squaw Peak, and to Whale Mountain, west of the fault. Ehlig (1988) also suggested that the north-vergent folds in the Cajon Formation imply a post-Squaw Peak transpressional event related to the modern San Andreas fault. His reconstruction called for minor normal slip on the Squaw Peak fault during 
deposition of the Cajon and Crowder Formations. Ehlig (1988), however, failed to account for several geologic observations. First, the granitic rocks, which he used to pin the Squaw Peak fault, underlie much of the San Bernardino Mountains and are neither petrologically nor mineralogically distinctive. Further, Silver et al. (1988) suggested that the granitic rocks from the DOSECC well do not form a single cogenetic suite. Their occurrence on both sides of the fault therefore does not limit the slip on the fault to less than the few tens of kilometers suggested by Meisling and Weldon (1989). Second, the folds that Ehlig (1988) believes indicate San Andreas transpression clearly predate the 4.2 Ma Phelan Peak Formation and are spatially related to the Squaw Peak fault rather than to the San Andreas fault. After removal of post-Phelan Peak tilting, these folds restore to south-facing monoclines. Their timing, distribution, and overall geometry are therefore compatible with south-directed thrusting. Finally, the assertion that the Cajon and Crowder Formations originated within the same basin (Ehlig, 1988) is inconsistent with observations of distinctly different clast assemblages and paleocurrent directions in the two formations (Woodburne and Golz,1972; Foster, 1980; Weldon, 1984; Reynolds, 1985).

If the Squaw Peak fault is a large thrust fault that slipped between 4.2 and 6.2 Ma, it has important implications for the regional geology of the Transverse Ranges. First, it requires that the Crowder Formation accumulated in a basin up to several tens of kilometers north-northeast of where it is now. Second, it provides a mechanism for uplift of the ancestral San Bernardino Mountains in the late Miocene (Meisling and Weldon, 1989). Third, it supports the correlation of the Squaw Peak fault with the Liebre Mountain fault made by Weldon (1986), Alexander and Weldon (1987), and Meisling and Weldon (1989).

This correlation, in turn, has important implications for the timing and magnitude of slip on the San Andreas fault. The Squaw Peak and Liebre Mountain faults are separated right-laterally by only $160 \mathrm{~km}$ along the San Andreas fault, $80 \mathrm{~km}$ less 
than the generally accepted $240 \mathrm{~km}$ of total San Andreas offset (Crowell, 1962, 1981). Furthermore, the correlation supports Matti et al. (1985) and Frizell et al. (1986) who suggested that Triassic monzogranite at Liebre Mountain is the offset equivalent of similar rocks in the San Bernardino Mountains. These monzogranites, also separated right-laterally by $160 \mathrm{~km}$, occur in the hanging walls of the Liebre Mountain and Squaw Peak faults respectively. A number of workers (Powell, 1981; Matti et al, 1985; Meisling and Weldon,1989) explain the "missing" $80 \mathrm{~km}$ of slip by suggesting that it took place on subparallel faults that predate the modern San Andreas fault.

Our study of the high-angle segment of the Squaw Peak fault found several lines of evidence that indicate this segment of the fault slipped right-laterally. This sense of slip is consistent with a ramp origin for the high-angle segment. The right-lateral motion occurred, however, after a significant amount of shortening oblique to the trace of the fault. Therefore, we believe that while the high-angle segment of the Squaw Peak fault is a lateral ramp, the earlier shortening events reflect different stages in its evolution.

\section{Stratigraphy of the Study Area}

\section{Cajon Formation}

The Cajon Formation consists of up to 2500 meters of arkosic sandstone and conglomerate deposited by southwestward-flowing streams (Woodburne and Golz, 1972) during late early to late middle Miocene time (Reynolds, 1985). Woodburne and Golz (1972) divided the formation into six members on the basis of grain size, color, and clast composition. The Cajon Formation within the study area consists entirely of the youngest member, member 6 . 
We divided member 6 within the study area into three submembers, based on grain size and stratigraphic position with respect to a prominent green siltstone bed, designated Tpg on Plate 1. The fine-grained submember, Tpf, lies everywhere in fault contact with the two coarse-grained submembers; therefore, its stratigraphic position with respect to the other two units is uncertain. We believe that Tpf lies stratigraphically beneath the coarser submembers, however, because rocks within the study area generally face eastward and Tpf lies to the west of the two coarse-grained submembers. The coarse-grained submembers are labelled $T p c 1$, which lies beneath the green siltstone, and Tpc2, which lies above the green siltstone. Neither submember displays a complete section; faults cut out the bottom of Tpc1 and the top of Tpc2.

The fine-grained submember, Tpf, consists of poorly-sorted, fine- to very coarse-grained arkosic sandstone with scattered bodies and stringers of conglomerate. Some of the finer-grained sandstone beds contain laminations while some conglomerate beds are matrix supported. Cross-bedding, although rare, occurs in some places. This unit has a faint pinkish-orange coloration which is most apparent when compared to the gray-white coarse-grained submembers.

Submember Tpc1, below the green siltstone bed, is the coarsest map unit in the study area. It consists of dominantly gray-white, coarse-grained, medium- to thickbedded conglomerate and about $30 \%$ sandstone and minor siltstone and shale. Conglomerates typically are poorly sorted, with subangular clasts up to $40 \mathrm{~cm}$ in diameter. They may be either matrix or clast supported and fill channels or smaller scours in the underlying rocks. Sandstone within this submember is generally coarse grained but locally consists of fine-grained green or brown sandstone and siltstone. It contains minor cross-bedding and/or heavy mineral laminations. The finer-grained rocks may occur as rip-up clasts in the coarser-grained sandstone and conglomerate. A paleosol occurs within this submember near the eastern end of the study area. 
Submember Tpc2, above the green siltstone bed, contains approximately equal amounts of sandstone and conglomerate, with minor siltstone and shale. Although the conglomerate in Tpc2 resembles that in Tpc1, it forms thinner beds, generally less than one meter thick. The sandstone of Tpc2 tends to be finer grained than that of Tpc1. It displays numerous fining-upwards sequences from coarse-grained to fine-grained sandstone, siltstone or shale, and typically contains laminations. Locally, the sandstone contains stringers of pebble- to cobble-sized clasts. Elsewhere it contains rip up clasts of brown fine-grained sandstone or siltstone. The uppermost part of Tpc2 that is exposed consists of predominantly fine- to coarse-grained sandstone and is almost devoid of conglomerate.

\section{Crowder Formation}

The Crowder Formation consists of about 1000 meters of arkosic sandstone and conglomerate, deposited by southward flowing braided streams (Foster, 1980) from 17 to 9.5 million years ago (Weldon, 1986). The formation occurs throughout the western San Bernardino Mountains with little lithologic variation. It thickens and contains finer grained facies to the west where it is cut by the Squaw Peak fault, suggesting that its basin center once lay to the west of the present trace of the Squaw Peak fault (Weldon, 1986).

Within the study area, rocks of the Crowder Formation belong to Member 4 as described by Weldon (1986). These rocks, labelled Tc, are dominantly brownishwhite, fine- to coarse-grained arkosic sandstone with minor siltstone, shale, and conglomerate. The conglomerate typically occurs in thin beds, $0.5 \mathrm{~m}$ or less, and contains poorly sorted angular to subangular clasts. The sandstone may be massive or laminated, locally showing cross laminations. In some places, interlayered conglomerate and sandstone display fining-upward sequences. 
The lowest part of the Crowder Formation that is exposed in the study area closely resembles the upper, finer-grained beds of Tpc2. The Crowder Formation, however, contains none of the purple and green volcanic or red sandstone clasts that appear in the Cajon Formation. In general, plutonic clasts within the Crowder Formation are less felsic than those in the Cajon Formation. Furthermore, the Crowder Formation is less indurated than the Cajon Formation.

\section{Structural Geology}

The study area lies immediately north of a gentle bend in the high-angle segment of the Squaw Peak fault and immediately south of where the fault turns to the WNW and becomes a thrust fault (Fig. 1). The site consists primarily of cuts along two parallel railroad tracks. Because the rocks are relatively soft, they erode rapidly, degrading the quality of the exposures. Still, as of spring, 1988, the outstanding exposures, especially those on steeper slopes, allowed us to map the railroad cuts at the scale of 1:500 using a plane table and alidade, and to define four stages in the area's structural evolution (Plates 1,2 Figs. 2A, B).

East-directed, west-directed, and northeast-directed shortening occurred during the first three stages respectively. Right-lateral strike-slip along the Squaw Peak fault postdated the shortening. Our determination of slip directions for these faults rely principally on stratigraphic separations, slip directions of minor, related faults, and fold orientations and vergences. Further, the geometry of some fault surfaces, namely, the Squaw Peak fault and minor faults within its zone of deformation, strongly suggest strike-slip motion. Striations occur on many fault surfaces in the study area but we did 
not rely on them as directional indicators because they formed on thick scaly mobilized clay gouge and typically showed wildly scattered orientations.

We recognized three structural elements in the study area (Plate 1). First, the relatively undeformed Crowder Formation, east of the Squaw Peak fault, consists of gently east-dipping beds which steepen towards, and are tightly folded at, the fault. The second and third elements are the lower and upper plates, respectively, of the highly deformed Cajon Formation, west of the Squaw Peak fault. These two plates lie below and above a shortening-related low-angle fault. While we will discuss the structures chronologically, it will be helpful to note in which structural element they occur.

The Plio-Pleistocene sediments that overlie the Squaw Peak fault dip an average of 25 degrees to the north-northeast. We removed this post-Squaw Peak tilting in our structural analysis by restoring the average dip vector, 25, N30E, to horizontal (figs. 3-5). Most significantly, several of the faults within the study area presently show normal separations but are clearly related to shortening. These faults, here called contractional faults, typically restore to original thrust or reverse fault geometries.

A high-angle fault juxtaposes Tpf with Tpc1, cutting bedding at low angles. The fault is well exposed in both the upper and lower plates of the study area, showing a range in orientations from N6W, 51E to N70W, 82S. After rotation of the PlioPleistocene sediments to horizontal, all known orientations of the fault restore to easterly or northeasterly moderate to steep dips (Fig 3A). This fault is problematical in both its slip direction and its age with respect to the other structures. A mullion-like irregularity on the fault surface restores to a subhorizontal plunge (3, S54E; Fig. 3A), suggesting lateral motion but if Tpf lies stratigraphically beneath Tpc1, the restored fault shows normal separation. It clearly predates the low-angle fault but bears an unknown relationship to the other contractional faults. Consequently, this fault plays an unknown role in the structural evolution of the study area. It does, however, occur in 
both the upper and lower plates, providing a planar marker to measure separation on the low-angle fault.

\section{First Stage}

The first stage of shortening represented by the fault labelled "West-Dipping fault" on the map, places an upright syncline of Tpc2 above overturned Tpc2. The westdipping fault varies in strike from N83W at its southernmost exposure to N32E, about 30 meters to the north. After removing Pleistocene deformation, the fault restores to orientations of N69W, 39SW and N2E, 42W respectively (Fig. 3B). At the southern exposure, bedding in the footwall strikes subparallel to the fault; at the northern exposure, the synclinal fold axis trends subparallel to the fault.

Several features suggest the west-dipping fault is related to the syncline in its hanging wall and the overturned syncline in its footwall. Minor faults with normal and reverse separations cut the hanging wall syncline at the southern exposure, apparently accommodating space problems caused by the folding. These minor faults merge with the west-dipping fault, suggesting that they, and the folding, were active concurrently with the West-Dipping fault. In one place, scaly gouge flows from the west-dipping fault into one of the minor faults. We interpret the west-dipping fault to be a thrust, placing older over younger rocks (Figs. 2A, B, C).

\section{Second Stage}

An east-dipping, probably reverse, fault cuts the west-dipping fault just north of the southern railroad tracks. There, this fault cuts bedding at high angles, but it becomes parallel to bedding a few meters to the north. The fault is marked by a layer of red scaly gouge, approximately $1-10 \mathrm{~cm}$ thick. We believe this fault is a backthrust for three reasons. First, it is bracketed in time by other contractional faults. Second, a smaller, subparallel fault with a west-verging anticline in its hanging wall occurs 
nearby. Third, the west-dipping fault, which it offsets, does not appear at the surface on the footwall side, as one would expect given normal slip. Reverse slip probably buried the footwall side of the west-dipping fault beneath the exposed hanging wall side.

\section{Third Stage}

The third stage of shortening is represented by a low-angle fault which separates the upper and lower plates. This fault shows a wide range of orientations, dipping gently to the north, south, east, and west. Removal of Pleistocene deformation restores these orientations to gentle southwestern and southern dips (Fig. 3C). Two observations suggest that this fault is related to the gently northeast-plunging recumbent syncline on the west side of the study area. First, the fold and fault are spatially related. Both lower and upper plate rocks steepen and overturn as they approach the fault, and the axis of the syncline restores to a gentle southeast plunge, approximately parallel with the strike of the fault (Fig. 3D). Second, minor faults, subparallel to the low-angle fault, cut the recumbent syncline and show small top-to-the-east separations.

Slip along the low-angle fault caused the syncline associated with the westdipping fault to be refolded into an antiformal syncline (Figs. $2 \mathrm{~B}, \mathrm{C}$ ). This refolding is also spatially related to the low-angle fault. The restored axis of the fold trends northwest, nearly parallel with the strike of the fault. Furthermore, the plunge of the fold axis reflects the dip of the fault. The axis plunges gently northwest at the north side of the study area where the fault dips gently to the north; it plunges 40 degrees southeast at the south side of the study area where the fault dips moderately southward. (Fig. 3E). Because axes of both the recumbent and antiformal syncline trend north-northwest they suggest that the upper plate of the fault moved to the east-northeast. Furthermore, minor faults that cut the recumbent syncline show small top-to-the-east separations.

The low-angle fault carried submembers Tpf and Tpc1 in the upper plate eastnortheastward, with a separation of about $150 \mathrm{~m}$ (Plate 2). The high-angle fault, which 
separates these two members, is also offset. No distinctive beds, however, including a paleosol in the upper plate and a green siltstone in the lower plate, are exposed on both sides of the fault. There are two plausible explanations for their absence. First, faults could have removed both the paleosol and the siltstone. The paleosol occurs next to the problematical high-angle fault while the expected upper plate location of the siltstone occurs on the Crowder side of the Squaw Peak fault. Second, because the railroad cuts are oblique to the transport direction of the low-angle fault, these distinctive rock types possibly did not have sufficient lateral extent to crop out on both sides of the fault. The paleosol, approximately $15 \mathrm{~cm}$ thick at the southern exposure, pinches out before reaching the northern exposure, about 30 meters away.

A smaller, gently east-dipping fault is spatially related to the low-angle fault and probably merges with it at the northwest corner of the study area. Near the northern railroad tracks, it offsets distinctive sandstone and conglomerate beds with about 5 meters of top-to-the-east, normal, separation; near the southern tracks it offsets the high-angle fault with about 10 meters of top-to-the-east separation. Although this fault presently dips eastward and shows normal separation, restoration to its original orientation shows that it originally dipped southward (Fig. 3C). Therefore, this fault was initially an eastward-vergent thrust fault.

\section{Squaw Peak fault}

The Squaw Peak fault cuts the low-angle fault, marking the last stage of deformation in the study area (Plate 2). Unlike the segments of the Squaw Peak fault which carried the Crowder Formation southward over the Cajon Formation, the Squaw Peak fault here brings the Cajon Formation over the Crowder Formation. The fault also exhibits dramatic changes in orientation within the study area, consisting of two highangle fault segments connected by a low-angle ramp. The most marked ramp geometry occurs immediately south of the northern railroad track where the Squaw Peak fault 
appears to merge with the low-angle fault. Immediately north of the northern railroad tracks where the ramp cuts the low-angle fault at a high angle, the ramp is much steeper. These relations suggest that the low-angle fault, in part, controlled the geometry of the Squaw Peak fault.

The change from a high- to low-angle surface occurs smoothly over a distance of less than three meters. It defines a cylindrical surface with an axis plunging $26, \mathrm{~S} 28 \mathrm{E}$ (Fig. 4A). The bend in the fault surface must be a primary feature, unrelated to later deformation, because bedding in the upper plate, adjacent to the bend, shows no such folding (Fig. 4B). Because this axis is the only line along which the entire continuous surface could slide, it probably parallels the slip direction of the fault. Adjacent to the fault, within a three meter wide zone of deformation, most nonplanar faults exhibit similar fault bend axes, oriented about 10, S40E (Fig. 4B, C). After removal of Pleistocene deformation, the slip line on the Squaw Peak fault surface restores to 36 , S41E; the average slip line in the deformation zone restores to 16, S54E. Because both sets of slip lines plunge gently southeast, they suggest a dominant strike-slip component of motion for this segment of the Squaw Peak fault.

Adjacent to the Squaw Peak fault, at the north edge of the study area, bedding in the Cajon Formation bends into parallelism with the fault in a sense consistent with right-lateral slip. Also, bedding in the Crowder Formation bends into the low-angle ramp segment in a sense suggestive of thrust motion. Because the ramp dips to the south and connects with the upper high-angle segment to the east, thrust motion on the ramp further suggests right-lateral motion on the high-angle segment.

Deformation in the Crowder Formation, adjacent to the Squaw Peak fault, is also consistent with right-lateral slip. Overall, the Crowder steepens towards the fault but is also faulted and folded into small anticlines and synclines. The anticline-syncline pair exposed on the south side of the northern tracks plunges 10, S44E; after rotation of the Phelan Peak Formation to horizontal it restores to 14, S50E (Fig 5A). The slightly 
oblique trend of these folds with respect to the Squaw Peak fault is consistent with right lateral slip. Furthermore, an anticline and syncline in the footwall and hanging wall, respectively, of an east dipping fault occur on the north side of the northern tracks. Plunges of these folds restore to 6, S60E for the anticline and 2, S72E for the syncline; the dip of the fault restores to 3, S28W (Fig. 5B). Because these folds and faults are perpendicular to each other, they are probably related; their oblique trend to the Squaw Peak fault suggests dextral slip.

\section{Discussion}

Although right-lateral motion on the Squaw Peak fault postdates motion on the contractional faults, three observations suggest that the lateral slip probably represents the culmination of one protracted episode. First, the intense shortening only occurs adjacent to the Squaw Peak fault; it abruptly dies out into relatively minor folding to the southwest and northeast. Second, the Squaw Peak fault slipped within the restricted time span of 4.2 to $9.5 \mathrm{Ma}$, possibly between 4.2 and $6.2 \mathrm{Ma}$. Third, within the study area, mobilized clay fills faults of all stages, indicating that they slipped under similar conditions during each period of deformation. Viewed in this context of one long episode, the four stages of deformation probably reflect evolution of the high-angle segment of the Squaw Peak fault.

Deformation within this study area differs from other areas where the Squaw Peak fault is exposed in both orientation and vergence. Structures along the low-angle segments of the Squaw Peak fault trend parallel to the fault and verge south and southwest, consistent with Weldon (1986) and Meisling and Weldon (1989) who suggested the Squaw Peak fault is a major southwest-directed thrust. Within this study area, structures trend obliquely to the Squaw Peak fault and verge to the east and 
northeast. Although spatially associated with the high-angle segment of the Squaw Peak fault, these structures are difficult to reconcile with southwest-directed thrusting. Weldon (1986) and Meisling and Weldon (1989) suggested the high-angle segment slipped right-laterally as a ramp connecting the two southwest-directed low-angle segments (Fig. 6). An evolving right-lateral fault may explain the oblique trend and general northeast vergence of the major structures within the study area.

The three stages of contractional faults in the study area reflect shortening oblique to the present trace of the Squaw Peak fault, approximately parallel to the expected shortening direction in a right-lateral shear couple. Furthermore, the different stages also show a counterclockwise progression in shortening direction which may reflect clockwise rotation of the faults during progressive simple shear.

Shortening during stages 1 and 2 was essentially east-west, at a high angle to the future trace of the Squaw Peak fault; shortening during stage 3 was northeast-southwest, at a smaller angle to the fault. This structural evolution resembles the wrench fault models of Wilcox et al (1973) where two laterally moving basement blocks formed a shear couple in the overlying material.

Slip on two adjacent but vertically separated thrust faults would create such a shear couple. Further motion along the thrusts would increase the amount of stress within the stepover zone, causing repeated episodes of folding and faulting; their sense of vergence would not necessarily conform to the thrust faults. Eventual propagation of a high-angle ramp connecting the low-angle segments would localize further deformation within the stepover region, being the most efficient means to transfer strain across it.

We propose that the high-angle segment of the Squaw Peak fault formed in a similar fashion. The two low-angle thrust segments formed first, creating a rightlateral shear couple that, in turn, caused northeast-southwest shortening and strain hardening. The high-angle segment then formed in response to the high stress buildup in the stepover region between the two low-angle segments of the fault. When the fault 
formed, connecting the two segments, it greatly lowered the local yield point and shut off the contractional structures.

\section{Summary}

Structures adjacent to, and associated with, the north-northeast trending highangle segment of the Squaw Peak fault are beautifully exposed in four east-trending railroad cuts near Cajon Pass. The structures display a four stage evolution. The first three stages occurred during northeast-southwest compression, oblique to the Squaw Peak fault; the fourth stage consisted of right-lateral strike-slip along the Squaw Peak fault. Because all four stages occurred during a single protracted episode rather than four separate events, they reflect the evolution of the high-angle segment of the Squaw Peak fault.

The high-angle segment connects the two west-northwest trending low-angle segments of the Squaw Peak fault, interpreted by Weldon (1986) and Meisling and Weldon (1989) as large south-directed thrust faults. These low-angle segments occur at significantly different structural levels suggesting the high-angle segment connects them as a lateral ramp (Weldon, 1986; Meisling and Weldon, 1989). Our interpretation of the structural evolution at the railroad cuts supports a ramp origin for the high-angle segment and requires thrust motion on the low-angle segments.

The contractional structures within the study area, which are oblique to the Squaw Peak fault, probably formed in a right-lateral shear couple parallel to the present strike of the high-angle segment prior to strike-slip motion. This shear couple was generated by thrust motion on the two vertically-separated low-angle segments. With continued thrusting, however, the high-angle segment broke through the earlier structures and connected the thrusts as a lateral ramp. 


\section{References}

Alexander, J., and Weldon, R.J., 1987, Comparison of structural style of the Liebre Mountain and Squaw Peak thrust systems, offset across the San Andreas fault, southern California (abs.): Geol. Soc. America Abs. with Programs, v. 19, p. 353 .

Crowell, J.C., 1962, Displacement along the San Andreas fault, California: Geol. Soc. America Special Paper 71.

Crowell, J.C., 1981, An outline of the tectonic history of southeastern California, in Ernst, W.G., ed., The Geotectonic Development of California (Rubey Volume 1). Englewood Cliffs, New Jersey, Prentice Hall, p. 583-600.

Ehlig, P.L., 1988, Geologic structure near the Cajon Pass scientific drill hole: Geophysical Research Letters, v. 15, p. 953-956.

Foster, J.H., 1980, Late Cenozoic tectonic evolution of Cajon Valley, southern California: Ph.D. Dissert., Univ. Calif. Riverside, Riverside, California, 235 p.

Frizzell, V.A., Jr., Mattison, J.M., and Matti, J.C., 1986, Distinctive Triassic megaporphyritic monzogranite: Evidence for only 160 kilometers of offset along the San Andreas fault, southern California: Jour. Geophys. Res., v. 91, p. $14,080-14,088$.

Matti, J.C., Morton, D.M., and Cox, B.F., 1985, Distribution and geologic relations of fault systems in the vicinity of the central Transverse Ranges, southern California: U.S. Geol. Survey Open File Report 85-365, 27 p.

Meisling, K.E., and Weldon, R.J., 1989, The Late-Cenozoic tectonics of the northwestern San Bernardino Mountains, southern California: Geol. Soc. America Bull., in press.

Powell, R.E., 1981, Geology of the crystalline basement complex, eastern Transverse Ranges, southern California: Constraints on regional tectonic interpretation: Ph.D. thesis, California Institute of Technology, 441 p.

Reynolds, R.E., 1985, Tertiary small mammals in the Cajon Valley, San Bernardino County, California: in Geologic Investigations along Interstate 15--Cajon Pass to Mannix Lake, California: R.E. Reynolds ed. Field trip guidebook for 60th meeting, Western Association of Vertebrate Paleontologists, p. 49-58.

Reynolds, R.E., 1984, Miocene faunas in the lower Crowder Formation, Cajon Pass, California: A preliminary discussion: in San Andreas fault--Cajon Pass to Wrightwood, Hester, R.L., and Hallinger, D.E., eds., Pacific Section, AAPG, Volume and Guidebook, 55, p.. 17-21.

Silver, L.T., James, E.W., and Chapple, B.W., 1988, Petrological and geochemical investigations at the Cajon Pass deep drillhole: Geophysical Research Letters, $v$. 15 , p. $961-964$. 
Strathouse, E.C., 1982, The Santa Ana Sandstone (Miocene in part) and evidence for late Cenozoic orogenesis in the San Bernardino Mountains: in Geologic Excursions in the Transverse Ranges, J.D. Cooper ed., Cal. State Univ., Fullerton, Fullerton, California, p. 97-102.

Weldon, R.J., 1986, The late Cenozoic geology of Cajon Pass; Implications for tectonics and sedimentation along the San Andreas fault: Ph.D. thesis, California Institute of Technology, Pasadena, California, 400 p., 12 plates.

Weldon, R.J., 1984, Implications of the age and distribution of the late Cenozoic stratigraphy in Cajon Pass, southern California: in San Andreas fault--Cajon Pass to Wrightwood, Hester, R.L., and Hallinger, D.E., eds., Pacific Section, AAPG, Volume and Guidebook, 55, p. 9-15.

Weldon, R.J., Winston, D.S., Kirschvink, J.L., and Burbank, D.W.,1984, Magnetic stratigraphy of the Crowder Formation, Cajon Pass, southern California (Abs.): Geol. Soc. America Abs. with Programs, v.16, p.. 689.

Wilcox, R.E., Harding, T.P., and Seely, D.R., 1973, Basic wrench tectonics: American Assoc. Pet. Geologists Bulletin, v. 57, p. 74-96.

Woodburne, M.O., and Golz, D.J., 1972, Stratigraphy of the Punchbowl formation, Cajon Valley, southern California: Univ. Calif. Publications in Geological Sci., v. 92, $57 p$. 


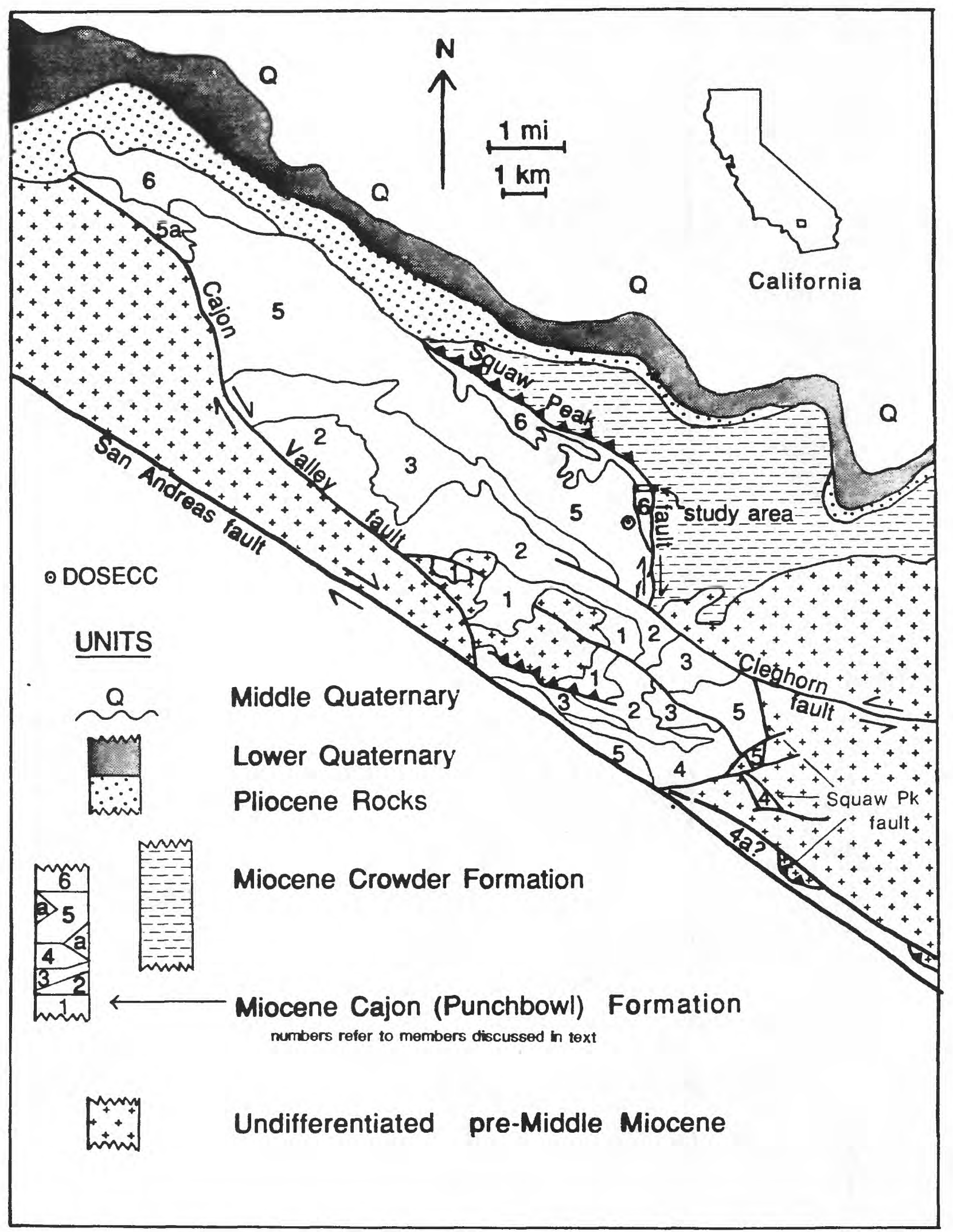

Figure 1. Map of the Cajon Pass area. The Squaw Peak fault continues south of the study area, placing undifferentiated pre-Middle Miocene rocks against the Cajon Formation. The fault's trace to the south, however, is discontinuous because it is offset by the Cleghorn and other faults. At its southern limit, the Squaw Peak fault trends NW and dips northward. There, it is cut by the San Andreas fault. 


\section{meters}
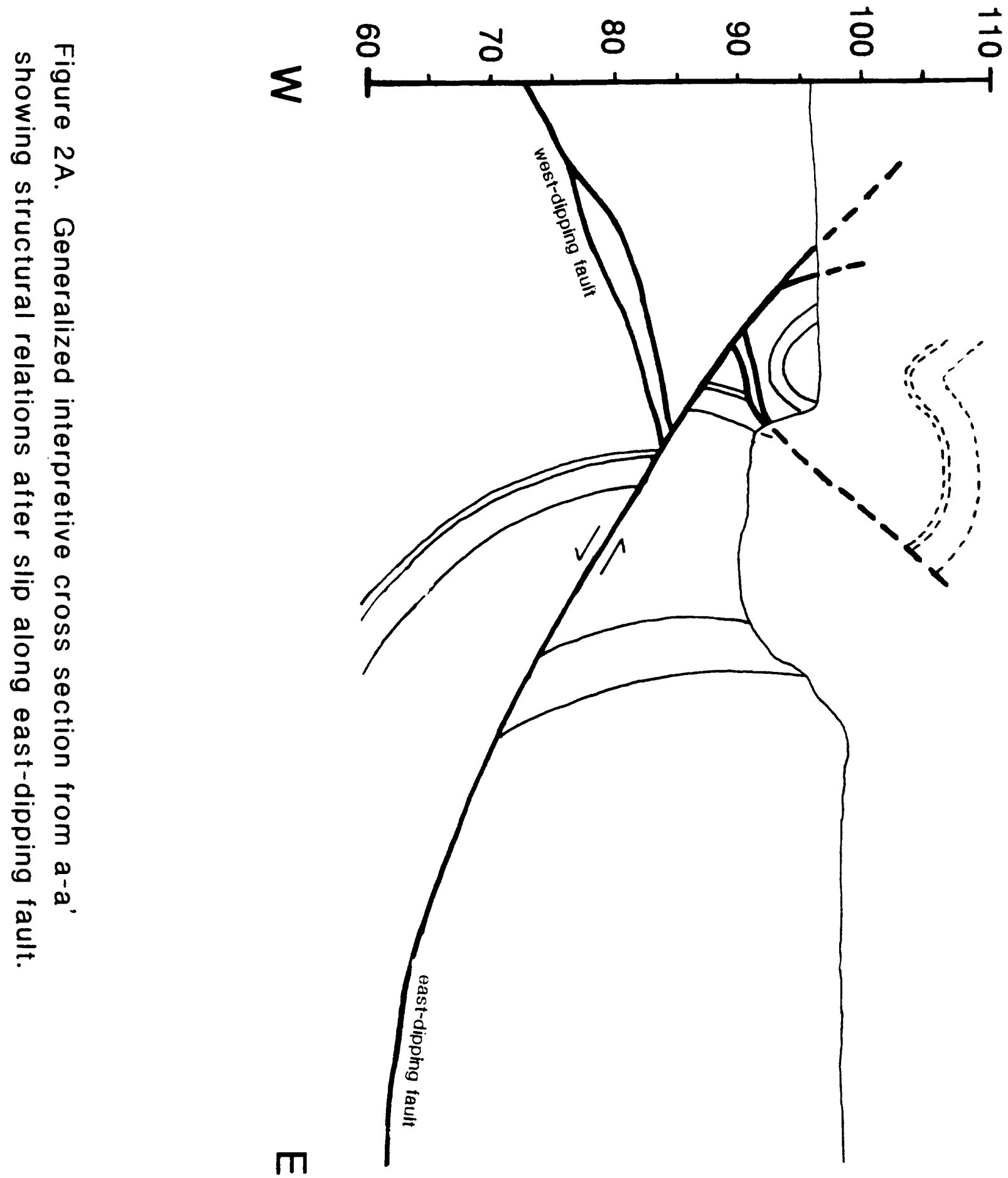

ค 
-

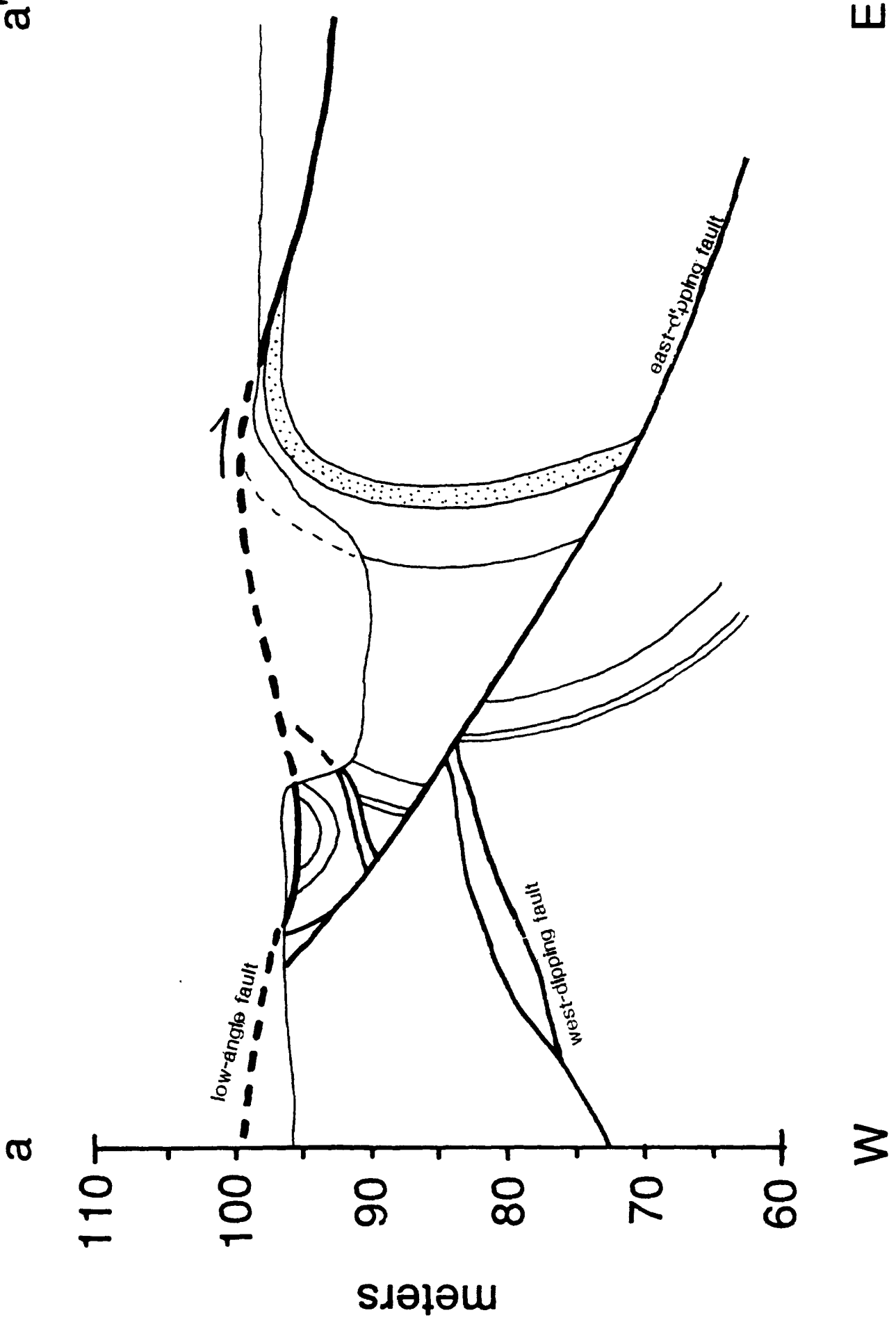

ํㅗㄴ

10

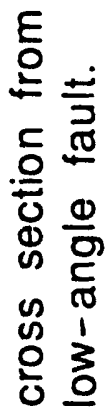

인은

$\stackrel{\Phi}{\stackrel{5}{ }} \frac{0}{\bar{c}}$

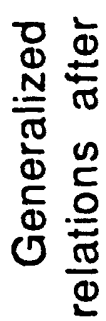

只

造站总 


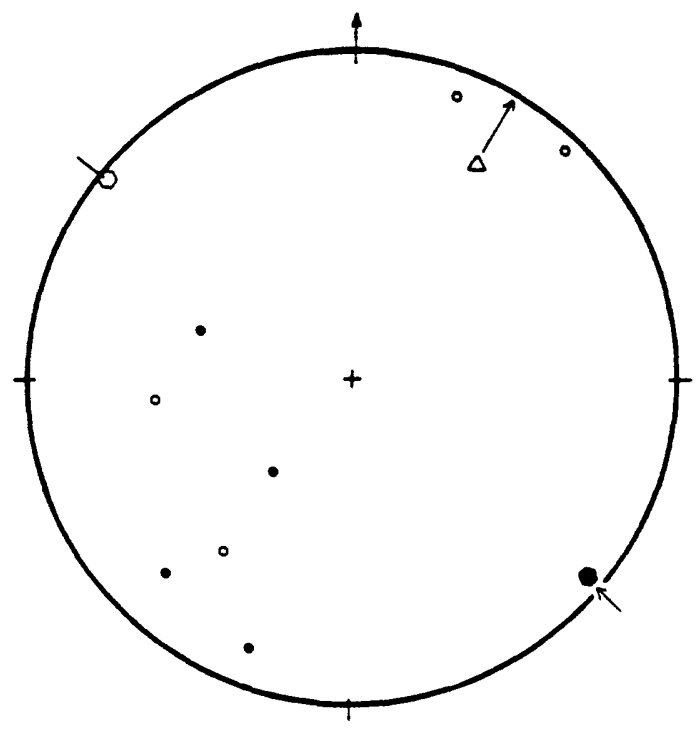

3A. Poles to high angle fault o; Irregularity on fault surface 0 .

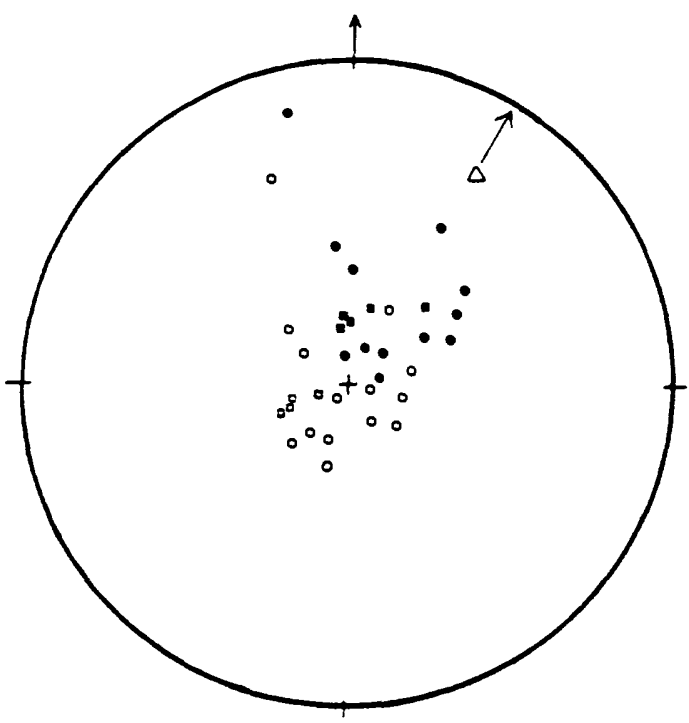

3C. Poles to Low angle faulto; poles to gently east-dipping fault o.

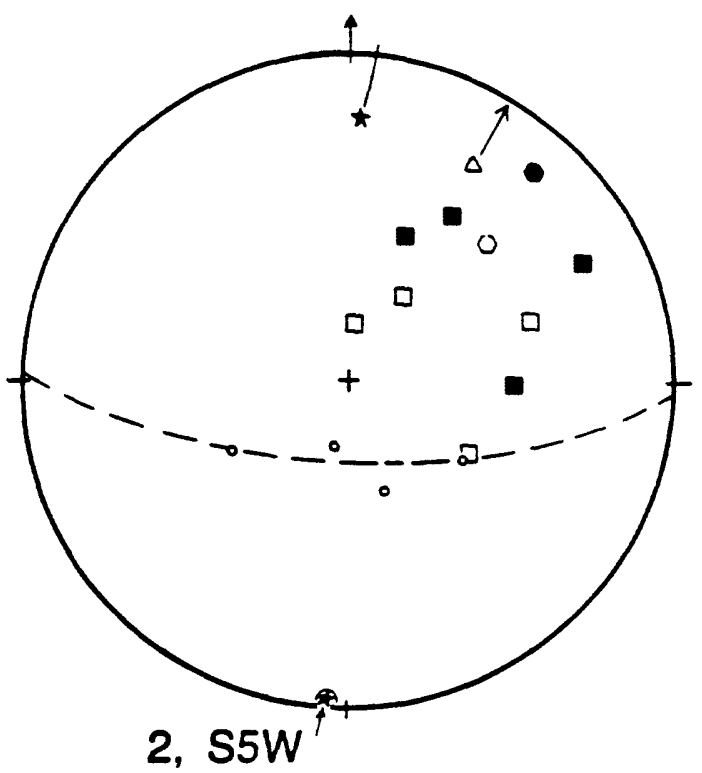

3B. Poles to bedding in hangine wall syncline of west-dipping fault 0 ; poles to west-dipping fault $\square$; poles to bedding below west-dipping faulto; fold axis 0

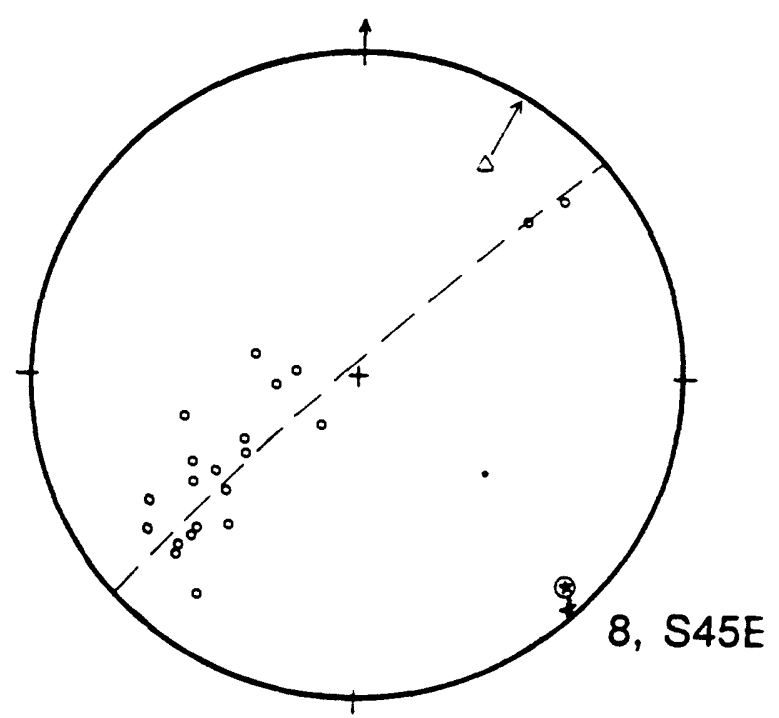

3D. Poles to bedding in recumbent syncline • ; fold axis $\star$. 


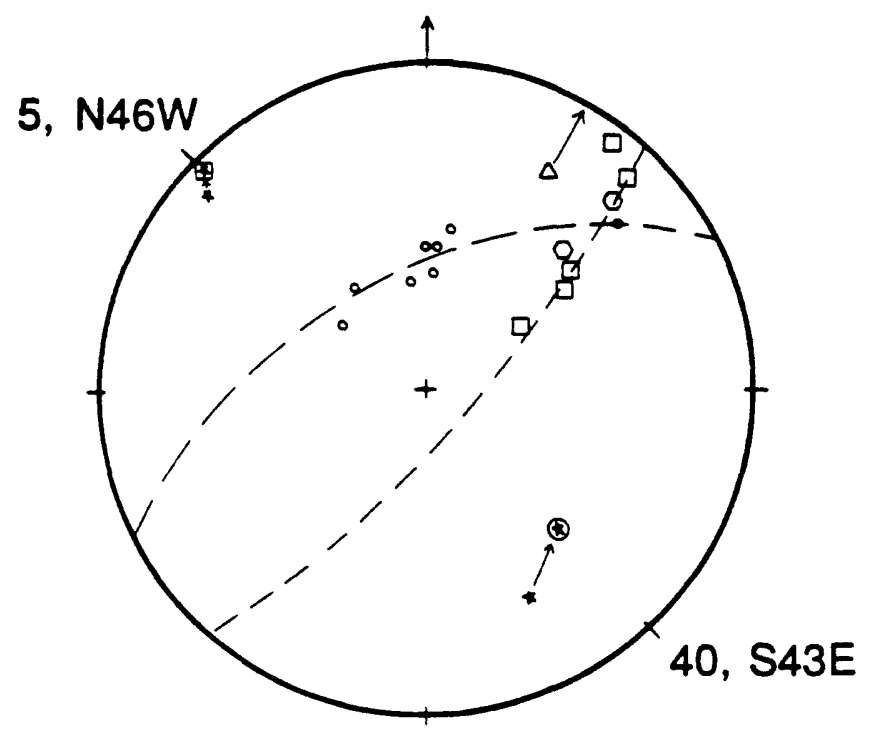

3E. Poles to bedding in antiformal syncline -- in south $\circ$; -- in north $\square$; in between $O$; fold axes $\star$.

Figure 3. Orientation data for: A. High-angle fault; B. West-dipping fault; C. Low-angle and gently east-dipping faults; D. Recumbent syncline; E. Antiformal syncline. In each figure, open symbols represent present orientations, closed symbols represent restored orientations. Restored fold axes are shown by an enclosed star. Restoration done by rotating overlying Phelan Peak Formation, shown by open triangle, to horizontal. 


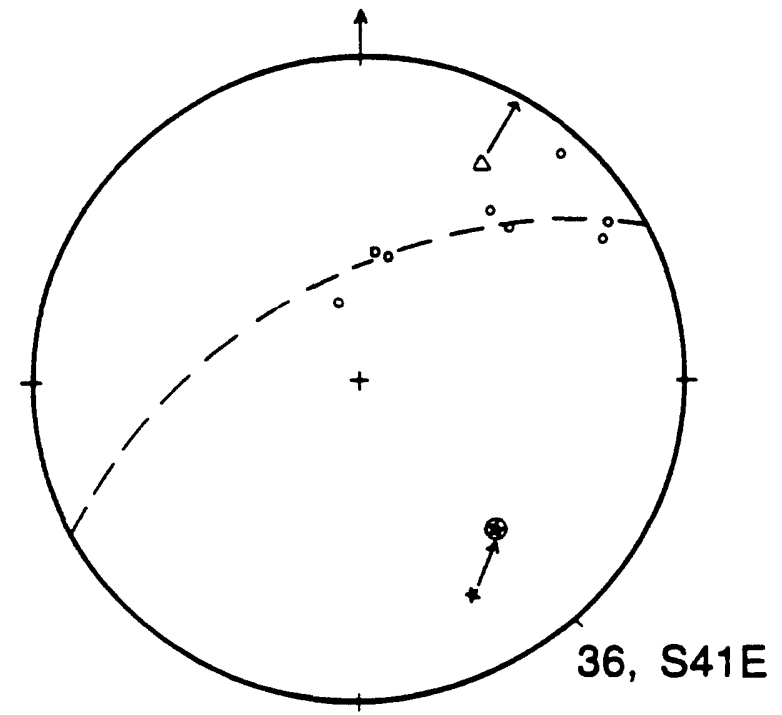

4A. Poles to Squaw Peak fault o; Slip line on fault $\star$.

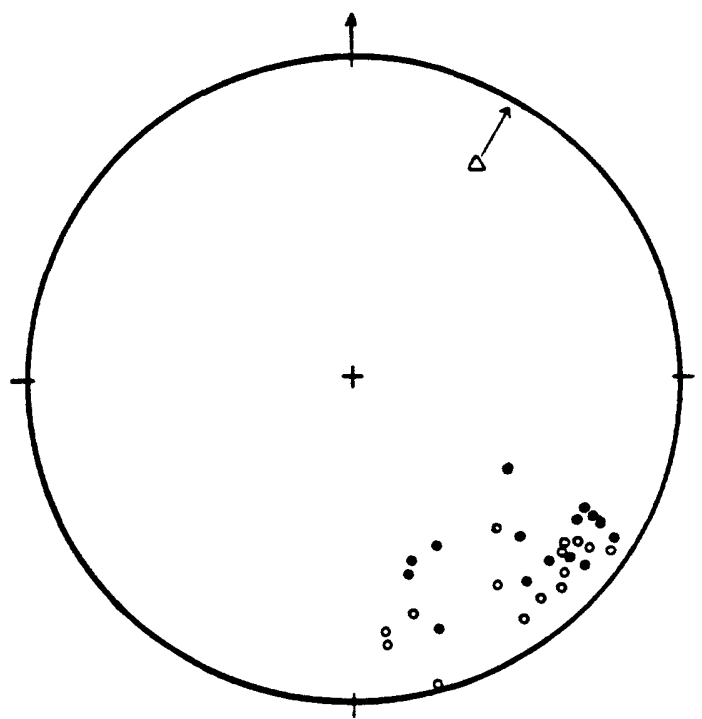

4C. Fault-bend axes on minor faults in deformation zone adjacent to Squaw Peak fault (see Fig. 4B) 0 .

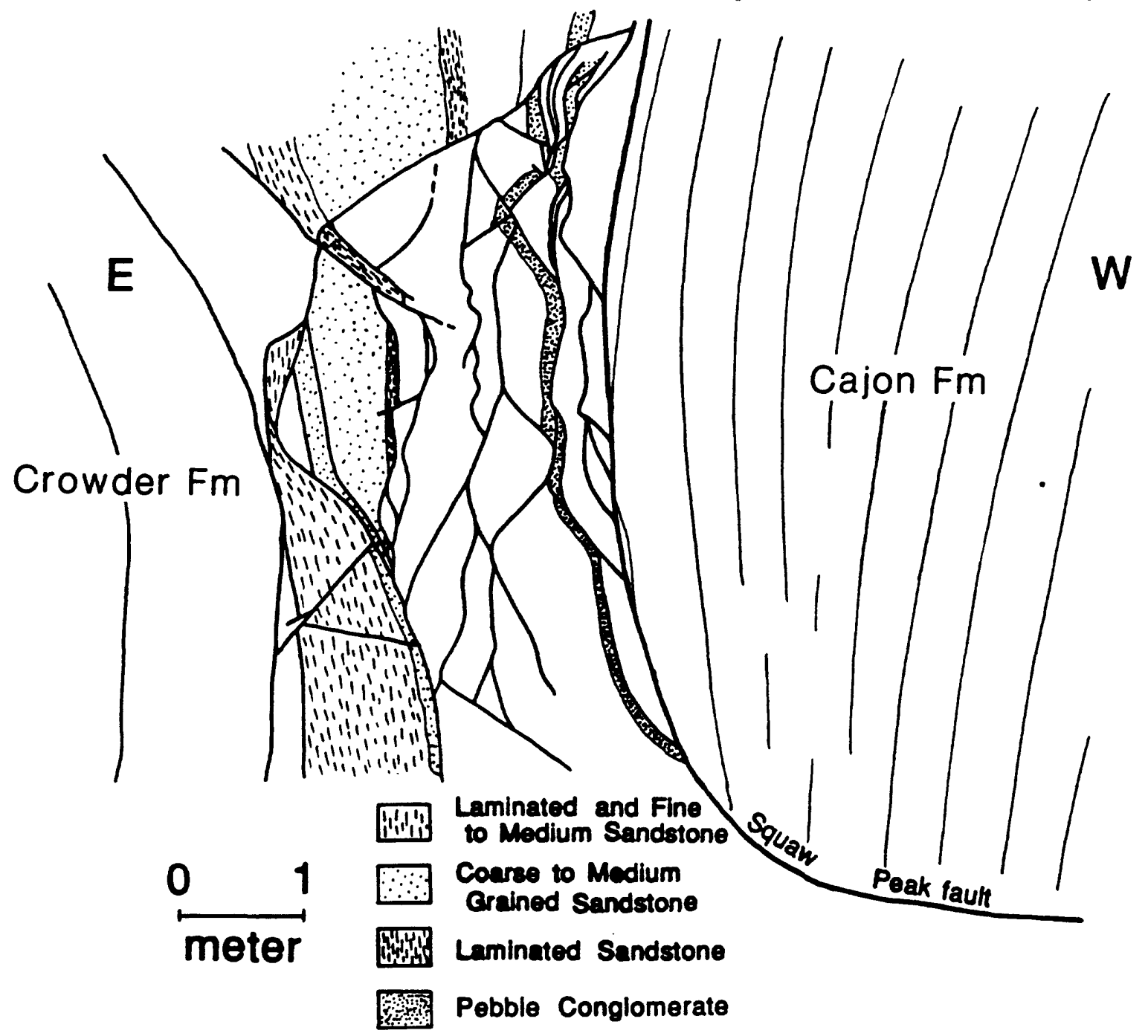

4B. Cross-sectional view of deformation zone adjacent to the squaw Peak fault. Note that the Cajon Formation is not folded at the fault, indicating that the fault surface is not folded either. Minor faults within the zone are markedly non-planar. 


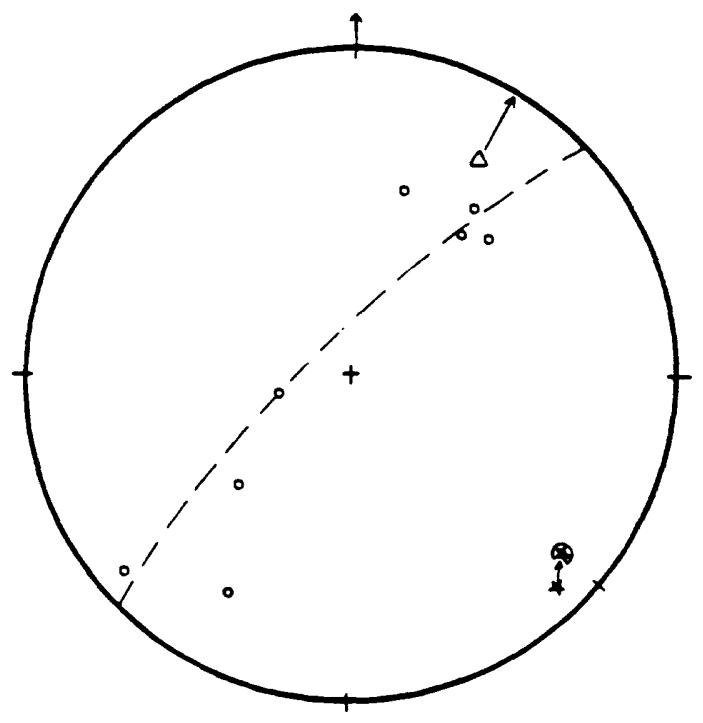

5A. Poles to bedding in anticline-syncline pair, Crowder Formation 0 .

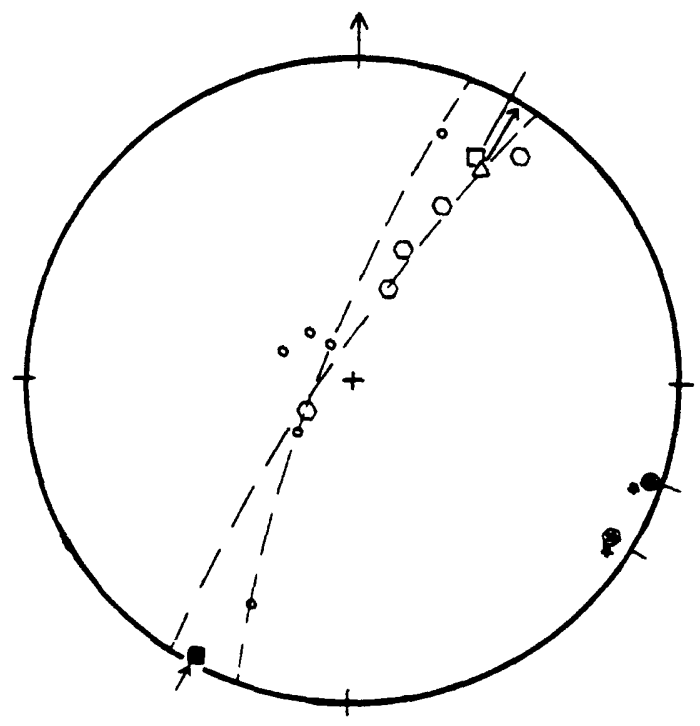

5B. Poles to bedding in syncline o, and anticline 0 , in Crowder Formation adjacent to the Squaw Peak fault; pole to the low-angle fault adjacent to the Squaw Peak fault 0 .

Figure 5. Orientation data for structures in Crowder formation adjacent to Squaw Peak fault. Open symbols show present orientations, closed symbols show restored orientations. 


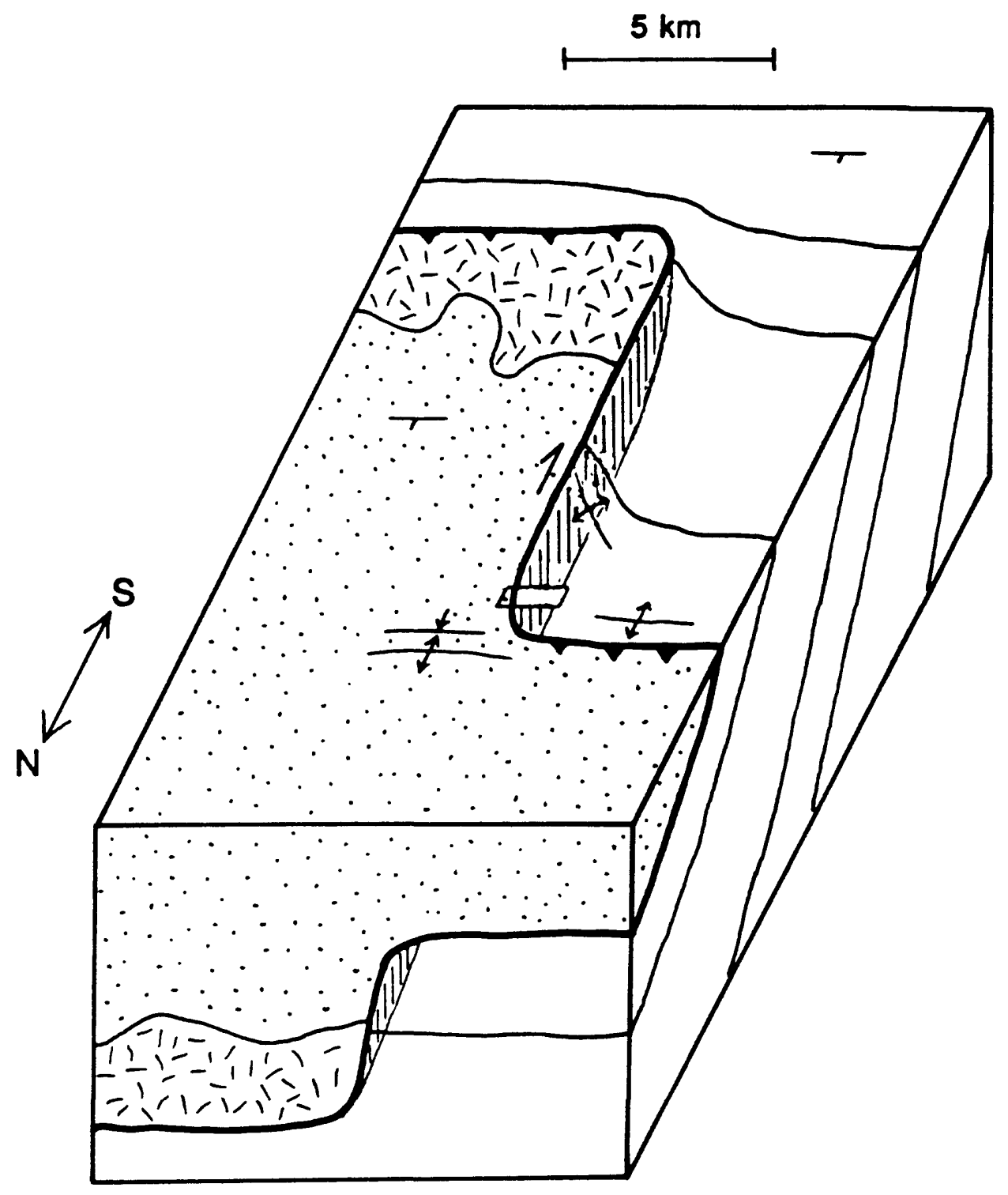

$\because \quad$ Miocene Crowder Formation

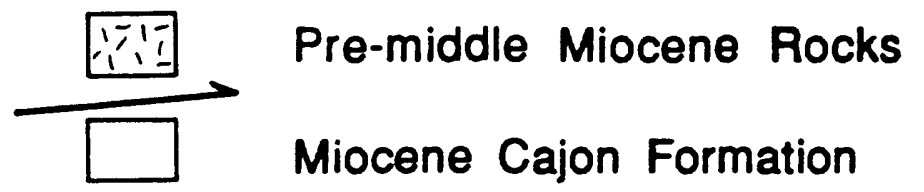

Figure 6. Schematic view, looking south, showing the relationship between the two low-angle segments and the high-angle segment of the Squaw Peak fault. High-angle segment is shown as a lateral ramp linking the two thrust segments. The study area is indicated by the rectangle along the high-angle segment. 